\title{
GENETIC VARIATION IN THE EPACRIS TASMANICA COMPLEX (EPACRIDACEAE)
}

\author{
by C. A. Gilmour, R. K. Crowden, R. E. Vaillancourt and A. Koutoulis \\ (with two text-figures)
}

\begin{abstract}
Glimour, C.A., Crowden, R.K., Vall.AncourT, R.E., \& Kouroulds, A., 2000 (31:xii): Genetic variation in the Epacris tasmanica complex (Epacridaceae). Pap. Proc. R. Soc. Tasm. 134: 75-78. School of Plant Science, University of Tasmania, GPO Box 25255, Hobart, Tasmania, Australia 7001.
\end{abstract}

\begin{abstract}
Random amplified polymorphic DNA markers (RAPD) were used to delimit species in the Epacris tasmanica complex (Epacridaceae) collected from various locations in Tasmania, Australia. The RAPD analysis placed morphologically similar taxa located closely geographically into discrete clusters. However, geographically distant populations of morphometrically similar taxa, such as the southern and northern Tasmanian populations of E. virgata and E. tasmanica, were less closely related to each other than those taxa classified as different species. The most geographically remote population (E. glabella [Serpentine Hill]) shared the least genetic similarities with the other taxa. The genetic information obtained from chis study reinforces some previous morphometric daca used to delinit species in the E. tasmanica complex. Furthermore, the strong geographical structure of the genetic variation is consistent with a model in which gene flow between populations is limited.
\end{abstract}

Key Words: Epacris tasmanica complex, genetic variation, RAPD analysis, endangered species.

\section{INTRODUCTION}

The Epacridaceae is one of the five main families that dominate Australian heathlands. The high level of endemism and localised distributions of the Epacridaceae leave many taxa susceptible to extinction. The Epacris tasmanica complex comprises seven closely related taxa, all of which are Tasmanian endemics (Crowden \& Menadue 1990). Historically, interest has been shown in the delimitation of species of this complex, primarily to clarify the taxonomic relationships between taxa. However, with the listing of six of the seven species of the complex as endangered or vulnerable (Flora Advisory Committee 1994), it is of interest to clearly identify discrete genetic entities to aid in their conservation.

The overlap of vegetative and floral characteristics between taxa in the E. tasmanica complex has made separation of distinct species difficult when using identification keys based on plant habit as well as leaf and sepal characteristics (Curtis 1963, Jarman \& Crowden 1977), which can be extremely plastic. Other attempts to delimit taxa in the $E$. tasmanica complex have used characters such as pollen surface patterns (Matthews 1965, 1966, Menadue \& Crowden 1991) and flavonoid chemistry (Jarman 1975). Crowden \& Menadue (1990) used numerical taxonomical methods to revise a key for the E. tasmanica complex and suggested there are seven taxa in the complex: E. tasmanica, E. virgata, E. apsleyensis, E. barbata, E. exserta, E. stuartii, and E. glabella (described by Jarman \& Mihaich 1991 as E. aff. exserta [Tunnel Hill]).

Molecular markers are simply inherited characters that distinguish or mark underlying genetic differences between individuals. It is believed that DNA markers are not severely influenced by selection (Avise 1994) and they have been increasingly used to study patterns of relatedness in natural populations (Ritland \& Ritland 1996). Randomly amplified polymorphic DNA (RAPD) markers have proved to be very effective in differentiating various degrees of relatedness (Williams et al. 1990, Cambecedes et al. 1999). They generally have been used within species but are also useful in population studies, when investigating complexes of closely related species; the E. tasmanica complex is such a complex. In fact, systematists are increasingly using RAPD markers and Harris (1995) demonstrated that groupings based on RAPD and restriction fragment length polymorphism (RFLP) analysis were essentially the same in species of Leucaena (Leguminosae). In the present study, RAPD markers were used to analyse genetic variation between members of the $E$. tasmanica complex collected from several locations in Tasmania, with a view to clarify the taxonomic relationships between members of this complex.

\section{METHODS}

\section{Tissue Collection and DNA Isolation}

Tissue samples were collected from 19 Tasmanian populations (fig. 1). New shoots and floral buds were collected from ten representative individuals in each population and individually stored at $4^{\circ} \mathrm{C}$ in airtight plastic bags, until processed (tissues were stored for a maximum of one week). Young tips were used, as it was expected that this tissue would contain less polysaccharide storage materials and, therefore, provide cleaner DNA compared to mature tissues. In the initial collection (June-July 1996) insufficient new growth was observed on the majority of plants to obtain enough tissue for individual DNA extraction. In some exposed populations, where growth was restricted by local severe environmental conditions (Southport Bluff [E, stuartit] and Cape Tourville $[E$. barbata] $)$, it was difficult to obtain fresh plant tissues. In the E. stuartii and E. barbata populations, tissue was collected from only eight individuals per population. Ar sites visited later (August-September 1996), when many of the Epacris species were beginning to flower, floral buds were also collected to determine their value as a DNA source. Where possible, paler coloured buds were preferentially selected to minimise anthocyanin levels, which might have hindered DNA extraction and analysis.

Preliminary DNA extraction trials showed that 2-5g of tissue were reçuired to obtain DNA. Due to the lack of available tissue for DNA extraction, tissues from individual plants were pooled in equal proportions to produce a mixture for each population (as discussed in Cambecedes et al. 1999). This procedure made it impossible to investigate 


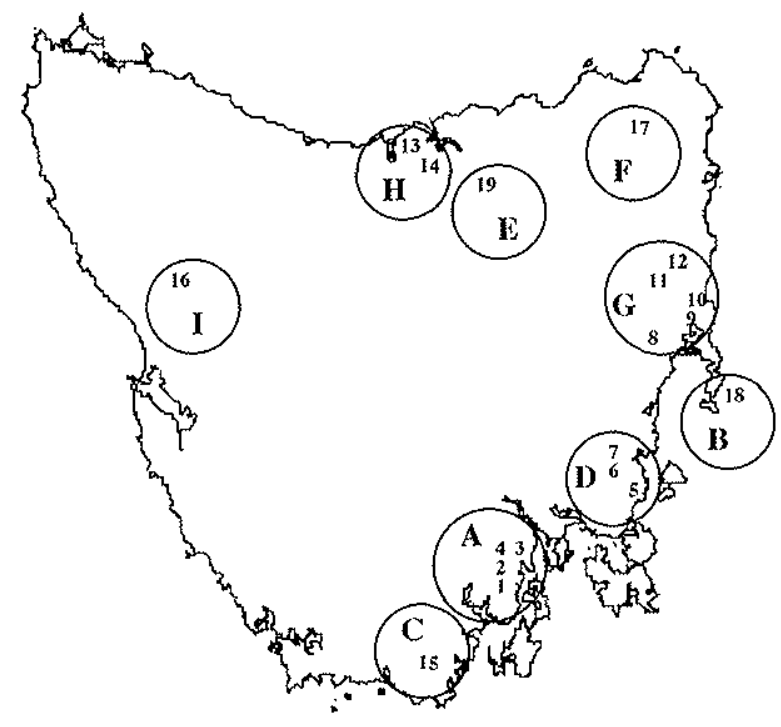

FIG. 1 - Collection sites (numbers) and RAPD groups (letters) for E. tasmanica complex populations. E. virgata (School Hill [1], Snug "High" [2], Van Morey Rd [3], Southern Outlet [4]); E. tasmanica (Hospital Creek [5], Buckland [6], Paradise Gorge [7], Lake Leake Rd [8], "O" Rd [9], Barbers Creek [10], Reynolds Hill [11], Hardings Falls [12]); E. virgata (Old Railway [13], Scots Hill (14]); E. stuartii (Southport Bluff [15]); E. glabella (Serpentine Hill [16]); E. virgata (Mt Cameron [17]); E. barbata (Cape Tourville [18]); E. exserta (Trevallyn Dam [19]). Letters delineate $R A P D$ groups defined in figure 2.

differences within populations; however, it enabled the efficient detection of differences among populations. Tissues were dried in McCartney bottles containing desiccator crystals, or frozen in liquid nitrogen and stored below $-60^{\circ} \mathrm{C}$ until DNA extraction. Preliminary extractions using floral buds produced high yields of DNA that possessed a similar amount of polysaccharide contamination to that observed in leaves. Consequently, where floral buds were collected, they were used in conjunction with leaf naterial. DNA was extracted by the CTAB (ceryltrimethyl ammonium bromide) method of Doyle \& Doyle (1990), using $5 \mathrm{~g}$ of tissue from each population $(0.5 \mathrm{~g}$ or $0.625 \mathrm{~g}$ from each plant when ten or eight samples were collecred per population, respectively). For several samples, particularly where leaf material was the only source of DNA, an additional chloroform-isoamyl alcohol extraction was performed prior to DNA precipitation to remove contaminants. To remove further contaminants, the salt concentration of the solubilised DNA was adjusted to $2.5 \mathrm{M}$ with ammonium acetate, and the solution was placed at $-20^{\circ} \mathrm{C}$ for 5 min. prior to extraction with phenol: chloroform (1:1). For most samples, the ammonium acetate and phenol:chloroform extractions were repeated at least twice. Following the cleaning up procedures, DNA was precipitated in cold ethanol, washed with ethanol, and resuspended in $500 \mu \mathrm{L}$ of 'T'E buffer to ensure that the different extraction methods did not effect amplification. DNA was quantified using a Hoefer TKO-100 Minifluorometer (Hoefer Scientific Instruments, USA) and diluted in sterile water to $3 \mathrm{ng} \cdot \mathrm{HL}^{-1}$.

\section{RAPD Analysis}

Various primer and magnesium ion concentrations for DNA amplification of Epacris species were tested. The best DNA amplification was obtained in polymerase chain reaction (PCR) mixtures ( $15 \mu \mathrm{L}$ final volume) containing $1.5 \mu \mathrm{L}$ Taq polymerase buffer $(\mathrm{x} 10)$, one unit $\mathrm{T}$ aq polymerase (Boehringer, Germany), $100 \mu \mathrm{M}$ of each dNTP, $1.6 \mathrm{mM}$ $\mathrm{MgCl}_{2}, 150 \mu \mathrm{g} \cdot \mathrm{mL}^{-1}$ BSA, $0.25 \mu \mathrm{M}$ primer and $12 \mathrm{ng}$ genomic DNA (modified from Williams ct al. 1990). DNA amplification was performed in a Corbett Research Fast Thermal Sequencer (FTS-960) (Corbett Research, Australia) programmed as follows: initial denaturation of $2 \mathrm{~min}$. at $94^{\circ} \mathrm{C} ; 35$ cycles of $1 \mathrm{~min}$. at $92^{\circ} \mathrm{C}$ denaturation, $1 \mathrm{~min}$, at $35^{\circ} \mathrm{C}$ annealing, $2 \mathrm{~min}$. at $72^{\circ} \mathrm{C}$ extension; and a final extension of 5 min. at $72^{\circ} \mathrm{C}$. A total of 23310 -base primers from UBC (University of British Columbia, Canada) and Operon (Operon Technologies, USA) were screened on the Lake Leake DNA samples (the most abundant sample of DNA). Only 18 of these primers were used in the final analysis, as they produced reproducible products (see Results).

Amplified PCR products were separated using a $1.4 \%$ $(\mathrm{w} / \mathrm{v})$ agarose gel in 'TBE buffer containing $0.5 \mu \mathrm{g} \cdot \mathrm{mL}^{-1}$ ethidium bromide. RAPD bands were visualised on an UV transilluminator and photographed using positive/negative polaroid film (Polaroid 665, USA). All polymorphic bands between 517 and 2645 base pairs were scored, while monomorphic bands were not scored. Each sample was scored manually for band presence (1) or absence (0) and data were recorded in the form of a binary matrix. A similarity matrix was generated using the Simple Matching Coefficient Function of NTSYS-pc (numerical taxonomy system of multivariate statistical programs for PC) (Rohlf 1993). The similarity matrix was used to generate an UPGMA (unweighted pair-group method with arithmetic mean) dendrogram using the SAHN (sequential agglomerative hierarchical non-overlapping) cluster analysis and UPGMA programs in NTSYS-pc (Rohlf 1993).

\section{RESULTS}

Of the 233 arbirary primers screened, 175 produced amplification of the Epacris DNA fragments to varying degrees. However, only 54 of these 175 primers produced RAPD amplification products which were clearly defined and had minimal background smearing. Due to reproducibility problems encountered with some primers, only 18 of the 54 primers were used in the final analysis (UBC $4,11,25,31,60,64,76,83,93,249$ and Operon D10, D13, F06, F07, F14, F20, M05, M18). These 18 primers produced 57 scorable polymorphic bands that were used to generate the similarity matrix and UPGMA dendrogram (fig. 2).

The UPGMA dendrogram demonstrates that populations in close geographic proximity formed tight clusters. The groupings do not correspond well to the previous described species, with the two more widespread species split geographically, with all the southeastern Tasmanian populations being grouped together, regardless of species, and geographically distinct populations of the same species from this region becoming more and more distinct. The $E$. virgata populations were divided into three groups, broadly corresponding to geography (figs 1,2). All populations that were sampled and described by Crowden \& Menadue 


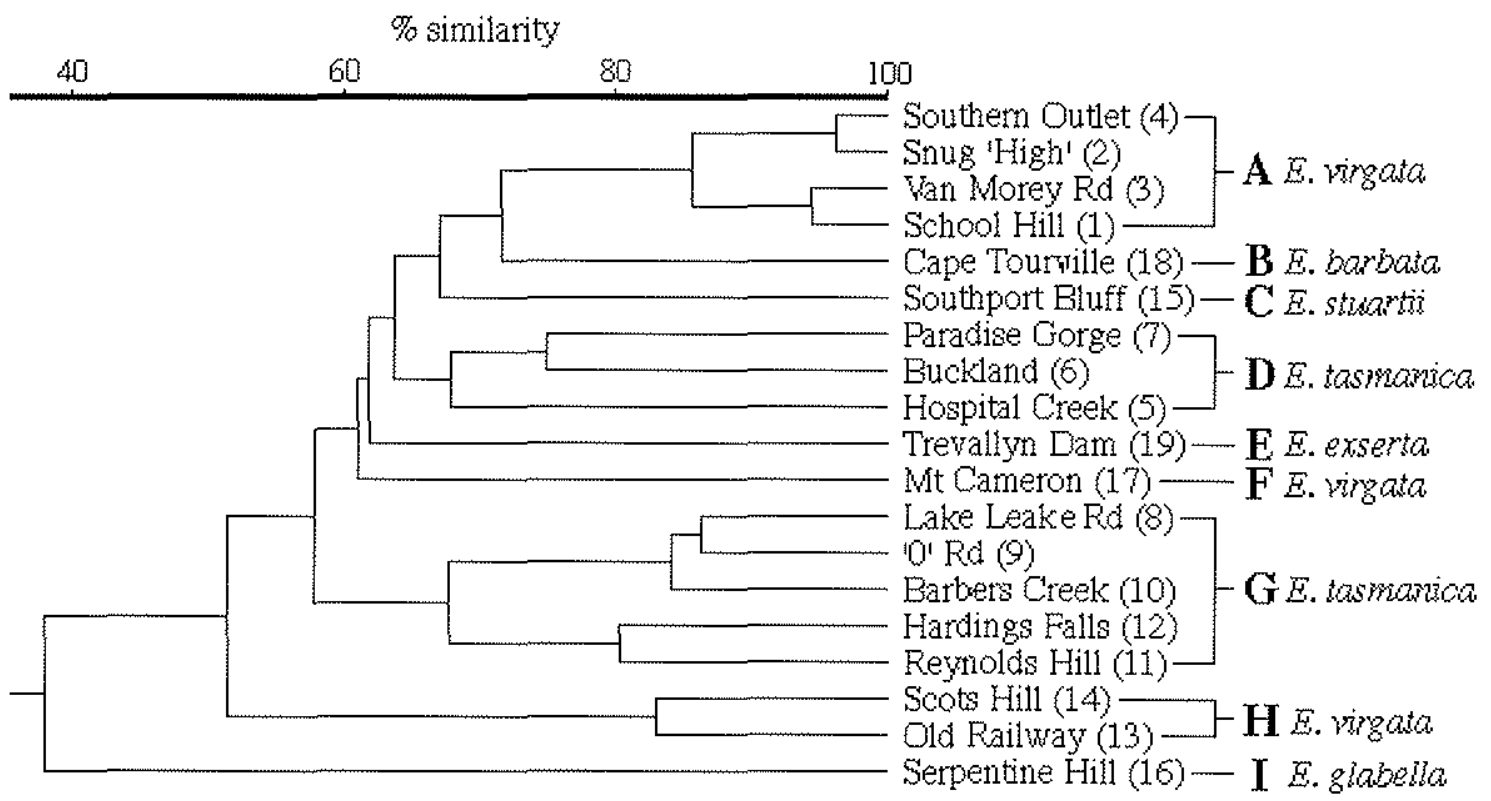

FIG. 2 - UPMGA dendrogram based on RAPD data obtained from populations of the E. tasmanica complex. Numbers in parentheses refer to the collection sites (fig. 1), while letters in bold refer to RAPD groups.

(1990) as southern $E$. virgata were tightly clustered, suggesting a close generic relationship between these populations (Group A). The two northern E. virgata populations (Scots Hill and Old Railway) also clustered together (Group H). Populations described as E. tasmanica formed two discrete clusters (Groups $D$ and $G$ ) separated by $E$. exserta (Trevallyn Dam) (Group E) and a putative disjunct population of E. virgata (Mt Cameron) (Group F) (see Discussion). The two E. tasmanica clusters do correspond broadly to geography, with populations within each group encompassing approximately $30 \mathrm{~km}$, while approximately $100 \mathrm{~km}$ separated the groups.

The dendrogram suggests that the E. glabella population (Group I) is an outgroup to the entire E. tasmanica complex. However, several primers gave no amplification in the $E$. glabella DNA. Consequently, data were lacking for several reactions, which may have biased the analysis. Interestingly, the positioning of $E$. glabella on the dendrogram does correspond to geography. E. glabella occurs in the far northwest of Tasmania, with its closest geographic neighbours being the northern $E$. virgata populations at Scots Hill and Old Railway (Group H).

\section{DISCUSSION}

The genetic data generated by RAPD markers have reinforced some of the taxonomic conclusions generated through the morphometric analyses of the Epacris tasmanica complex by Crowden \& Menadue (1990). The formation of distinct clusters, representing both the same species and similar geographic locations of the populations, suggests a relationship between the geographical location of the population and genetic distances between populations. The overall small differences in genetic similarities between clusters, suggests a close relationship between all members of the E. tasmanica complex.

Interestingly, not all RAPD results correspond to the morphometric data of Crowden \& Menadue (1990).
Although morphometrically similar, there is substantial genetic differentiation between the southern (Group A) and northern (Group $\mathrm{H}$ ) E. virgata populations. According to Crowden \& Menadue (1990), the northern E. virgata population flower measurements are at the smaller end of the $E$. virgata range but are otherwise indistinguishable from the southern E. virgata population. The data, therefore, support a model in which gene flow between populations is limited and local differentiation has occurred. Interestingly, the E. virgata population at Mt Cameron shows considerable genetic differentiation from both the southern and northern E. virgata populations. Crowden \& Menadue (1990) tentatively regarded this taxon (originally lodged in the Tasmanian herbarium as $E$. aff. exserta $[\mathrm{Mt}$ Cameron]) as an outrider population of E. virgata, based on overall habit and appearance. The data in this study add credence to the argument that the $E$. virgata population at $\mathrm{Mr}$ Cameron is a well-differentiated population (Crowden \& Menadue 1990). Clearly, the $E$. virgata populations at Mr Cameron and at other Tasmanian sites not sampled in this study (e.g. Murdunna and Hospital Creek) require further investigation to determine their genetic relationship within the complex.

Crowden \& Menadue (1990) suggested that, due to flower type and other shared morphological characteristics, $E$. stuartii and E. glabella are more closely related to E. virgata (both southern and northern populations) than $E$. tasmanica. However, the RAPD data suggest that $E$. glabella (Group $\mathrm{I}$ ) and the northern $E$. virgata populations (Group $\mathrm{H}$ ) are not closely related to the southern $E$. virgata (Group A) and E. stuartii (Group C) populations. Furthermore, researchers have suggested that E. barbata is more closely related to $E$. tasmanica than $E$. virgata (Menadue \& Crowden 1991); however, the RAPD data presented in the present study cannot address this issue. Unfortunately, RAPD data are lacking for the newly described $E$. aspleyensis, so it is not possible to determine its genetic relationship to the other members of the E. tasmanica complex. 
The association of geographic separation and genetic similarity observed in the dendrogram may, in part, explain these discrepancies. "The geographical distance between the southern and northem $E$. virgata and $E$. tasmanica populations would appear to effectively prevent an exchange of genetic material between populations. Over time, drift and different environmental selective pressures at each site would gradually alter the genetic composition of the taxa. Such a scenario would explain the genetic dissimilarity observed between southern and northern $E$, virgata and $E$. tasmanica populations; howcver, the question of the maintenance of morphological similarities remains unanswered. Additionally, the dose proximity of the southem E. virgata and southem E. tasmanica populations and their genetic similarity could indicate the mixing of genetic material without a noticeable effect on morphology. The premise that geographical isolation is correlated with genetic variation between related taxa is further illustrated by the positioning of other isolated populations (i.e. $E$. stuartii [Southport Bluff], E. barbata [Cape Tourville], E. virgata [Mt Cameron], E. virgata [Scors Hill and Old Railway Line] and $E$. glabella [Serpentine Hill]). Potts \& Jordan (1994) reported that populations of Eucalyptus globulus from relatively isolated localities often showed larger genetic variation when compared to less isolated populations, due to inbreeding and localised selective pressures. A study of the genetic variances within the populations could clarify whether there is a high degree of inbreeding in these populations.

Subtle differences in leaf morphology, corolla tube length and geographic isolation of members of the E. tasmanica complex, are considered sufficient reasons to maintain $E$. stuartii and $E$. glabella as distinct species (Crowden \& Menadue 1990). The RAPD data generated in this study supports the maintenance of $E$, glabella as a distinct species; however, this is less clear for E. stuartii. Interestingly, Keith (1996) suggested that the distinctiveness of E. stuartii from other taxa in the E. tasmanica complex could be strengthened by including several other characters, such as leaf thickness and lustre, inflorescence length, width of basal and ultimate branches, and habit.

In conclusion, this RAPD analysis of the E. tasmanica complex placed populations of morphologically similar taxa into discrete clusters, which corresponded (in varying degrees) with the geographical location of the populations within the $E$. tasmanica complex. The division of $E$. virgata and $E$. tasmanica into southern and northern groups is consistent with a model in which gene flow between populations is limited and should be investigated further. The fact that not all RAPD results corresponded to the morphometric data of Crowden \& Menadue (1990), suggests that it may be simplistic to assume that one methodology is sufficient to address the taxonomic issues in the E. tasmanica complex. Further research, therefore, should have a combinatorial approach and include morphological, genetic and breeding systems.

\section{REFERENCES}

AVISI, J.C., 1994: MOLECULAR MARKERS, NATURAL HISTORY AND EVOLUTION. Chapman and Hill, USA.

CAmbecledes, J., POTtS, B.M. \& VallanCourt, R.E., 1999: Morphological and genetic variation in Centrolepis paludicola and C. monogyna (Centrolepidaceac). Aust. Syst. Bot. 12: 679-688.

CROWDEN, R.K. \& MENadU:, Y., 1990: Morphometric analysis of variation in the 'Epacris tasmanica complex' (Epacridaceac). Aust. Syst. Bot. 3: 253-264.

CURTIS, W.M., 1963: THE STUDENT'S FLORA OF TASMANIA, PART II. Govemment Printer, Hobart.

Dovis, J.J. \& DorI.E, J.L., 1990: Isolation of plant DNA from fresh tissue. Focus 12: 13-14.

FIORA ADVISORY COMMITTE, 1994: NATIVE HIGHER PLANT TAXA WHICH ARE RARE OR TYHREATENED IN TASMANIA: SPECIES AT RISK. Parks and Wildlife Service of Tasmania, 'Tasmania, Australia.

HARRIS, S.A., 1995: Sysrematics and randomly amplifed polymomphic DNA in the genus Letucaena (Leguminosae, Mimosoideac). Plant Syst. Evol. 197: 195-208.

JARMAN, S.J., 1975: Experimental taxonomy in the Family Epacridaceac. Unpubl. PhD thesis, Univ, Tasm.

JARMAN, S.J. \& CROWDEN, R.K., 1977: AN IDENTIFICATTON KEY TO THE EPACRIDACEAE IN TASMANIA. University of 'Tasmania Press.

JARMAN, S.J. \& MilAICH, C.M., 1991: Additions to the Epacridaceac in Tasmania. Pap. Proc. R. Soc. Tasm. 124: 99-103.

KEITH, D., 1996: Recovery plan - Epacris stuartii Stapf. (Project No. 423). Australian Nature Conservation Agency, Canberta, AC'T.

MAThews, J.M., 1965: Warted pollen grains of Epacridaccac. Nature 208: 803-804.

Matritews, J.M., 1966: Some descriptions of the pollen morphology of Epacris Forst. emend. Cav. P'ollen et Spores 8: $461-478$.

Minadus, X. \& CRowdin, R.K., 1991: The taxonomic value of pollen surface patterns in some Australian Epacris (Epacridaceae). In Banks, M.R. et al. (Eds): ASPECTS OF TASMANIAN BOTANY - A TRIBUTE TO WINIFRED CURTYS. Royal Society of Tasmania: $113-$ 117.

Porrs, B.M. \& Jonban, G. ., 1994: The spatial pattern and scale of variation in Eucalyptus globulus labill. ssp. globulus: variation in seedling abnomalities and early growth. Aust. J. Bot. $42: 471 \cdots 492$

RITLAND, K. \& RTTLAND, C., 1996: Inferences about quantitative inheritance based upon natural population structure in the yellow monkeyflower, Mimulus gutatus. Evolution 50: $1074-1082$.

ROH!, E.J., 1993: NTSYS-PC, NUMERICAL TAXONOMY AND MULTIVARIATE ANALYSIS SYSTEM (VI.8). Exeter Software, Serauket, New York.

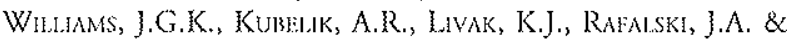
'THNGEY, S.V., 1990: DNA polymorphisms amplified by arbitrary primers are useful as generic markers. Nucleic Acid Res. 18: 6531-6535.

(accepted 30 October 2000) 